\title{
Derivation of Organizational Developments from Human Resources-An Evidence from it Sector in Chennai Region
}

\author{
B Jananee, M.Thaiyalnayaki
}

\begin{abstract}
In a larger context Organizational development (OD) refers to empowering the people and enabling them to use their power for development of the organization to which they belong and society at large. It refers to developing pro-activity and capacity to embrace larger issues. Considering the vital importance to human resources, they are now being treated as assets which are most precious for the survival of the organization. New values are being added. There has been shift from traditional master-slave relationship to the modern trusteeship system (in which employers and employees are considered as partners investing their wealth and labor respectively) and from traditional salary administration to the new Human Resource System (HRS). Human resources being a part of the organization, $O D$ is a sub system of larger system i.e., the organization. And $O D$ is the center of HRS and most vital for the organizational advancement. OD includes both the development of the people and development of the organization.
\end{abstract}

Keywords : Organizational development, HRS, Sub system.

\section{INTRODUCTION}

Several scholars have noted that managing people is more difficult than managing technology or capital (Barney, 1991; Lado and Wilson, 1994). However those firms that have learnt how to manage their human resources well would have an edge over others for a long time to come because acquiring and deploying human resources effectively is cumbersome and takes much longer (Wright et al., 1994).

Human resources can help firms improve organizational development in such areas as staff commitment, competency and flexibility, which in turn leads to improved staff performance (Koch and McGrath, 1996).

In order to develop a sound human resources, the organization should have effective Human Resource Management practices.Human resources refer to organizational activities directed at managing the pool of human resources and ensuring that the resources are employed towards the fulfillment of organizational goals (Schuler \& Jackson, 1987; Schuler \& MacMillan, 1984; Wright \& Snell, 1991). Human resources may differ from one organization to another and from one country to another.

Revised Manuscript Received on July 22, 2019.

B Jananee, research Scholar, Department of commerce, VISTAS, VELS University Chennai, India

M.Thaiyalnayaki, Research guide, HOD Department of BBA, VELS University Chennai, India

\section{LITERATURE REVIEW}

HRM is the organization's primary means for sending role information through the organization, supporting desired behaviors, and evaluating role performances; it is effective, therefore, when it communicates internally consistent expectations and evaluates performances in ways that are congruent with the system's behavioral requirements By implication, effective HRM helps employees meet the expectations of role partners within the organization (i.e. supervisors, peers, subordinates), at organizational boundaries (i.e. customers and clients), and beyond (i.e. family and society). Thus the expectations of these role partners must be incorporated into an understanding of HRM in Context.

Monica Ordiz and Esteban Fernandez, August 2005

The findings reveal that the adoption of practices that affect workers' motivation and involvement must necessarily produce an improvement of results; however, it is possible that these may be more observable for specific cases like service companies or those that develop their activity in very competitive environments.

Eric $\mathrm{Ng}$ Chee Hong, Lam Zheng Hao, Ramesh Kumar, Charles Ramendran, Vimala Kadiresan, 2012

This study reveals an opportunity for organization to manipulate these four aspects to attract potential talents. By establishing a reputable image as an organization, the organization will directly become favorites among the workers. When an organization is able to motivate its employees in a more specific manner, it will directly increase productivity and efficiency of its operation.

Darwish, Tamer K.Singh, Satwinder, Mohamed, A. Fattaah, Dec2013

This study provide strong support for the direct approach in strategic HR management performance research that a group of best HR practices will continuously and directly generate superior performance. 
It is possible that the optimal configuration may not only be contingent on national context, but could be due to the sector and the specific characteristics of the firm.

Maroudas, Leonidas, Kyriakidou, Olivia Vacharis, Artemis, Jul-Oct2008

The findings of the present study reveals two initial recommendations that provide quality training and development programmes; and consider the provision of financial benefits that make sense to the employees.

Stone, Dianna Stone-Romero,

Eugene $\quad F$

,Lukaszewski, Kimberly M., Jun2007

The findings reveal that cultural diversity of U.S. organizations is increasing rapidly. In spite of this, relatively little attention has been paid to the impact that the increase in diversity may have on the acceptance of human resource management processes and practices (e.g., recruitment, selection, training, performance appraisal, and compensation and benefits) by individuals and the effectiveness of such processes and practices.

\section{Derivation of Organizational development}

HR system has significant higher scores on productivity and lower scores on employee turnover than the control oriented steel mills. Arthur's (1994) analysis however is on organizational level. Traditional (control) work systems are characterized by narrowly defined jobs, specialization of employees, close supervision and monitoring of employees by management, hierarchical structure, centralization of power and a focus on cost reduction strategies. In contrast, the commitment work systems encompass broadly defined jobs, job rotation, evaluation by peers, non-hierarchical structure, decentralization of power and a focus on differentiation strategies

\section{Loo-See Beha and Leap-Han Looa, 2013}

The finding concludes that there is positive link between HRM effectiveness and firm performance. The practices of HRM undertaken in this study are concerned with how people are employed, managed, developed, rewarded, and taken care of as to achieve competitive advantage through the strategic deployment of a highly committed and capable workforce

Ullah, Irfan, Yasmin, Robina, Aug2013

These findings revealed the importance of internal customers in enhancing employee morale, organizational commitment, employee productivity, turnover rate and the organization's ability to attract talent.
Clint Chadwick, July 2007

He concludes that linear estimations of these relationships could mislead theorists and result in faulty recommendations to practitioners.

Heneman, Herbert G., Malinowski, Anthony T, Jan/Feb2011

The findings reveal that the link between HR practices and organizational performance has great strategic potential to drive organizational effectiveness. To capitalize on this potential, the organization must design and deliver HR practices that focus on necessary employee performance competencies, creating an HR system with vertical and horizontal alignment around those competencies.

\section{Joaqui'n Camps and Roberto Luna-Arocas May 2009}

Our findings can be interpreted as an indication that within the differentiation strategy context, High involvement work practices and firm performance implementation is easier when strong values and low levels of centralization are found in the organization. An eminently HR literature current is therefore corroborated, which favors the intensification of a 'humanizing' work practice, especially if the aim is to achieve a correct implementation of competitive strategies which require the workers' implication in the process

\section{Research Objectives}

1.The main aim of this research is to identify existing organizational development and IT employees perception over the Human resouces.

2.The research also aims at deriving the influence of the organizational variables of employees over the perception of Human resources and Organizational development.

\section{HYPOTHESIS}

\section{There is no relationship between Human resources and Organizational development. Research Methodology}

The study is based on both primary and secondary data The primary data is obtained through a structured questionnaire which consists of various human resource practices pertaining to top level executives, middle and operational level employees in the top IT companies in Chennai.

The researcher approaches all 3 types of executives in these companies and obtained 22 responses from top level executives 58 responses from middle and 63 responses from operational level employees. A separate questionnaire is administered for 3 types of executives independently and responses are obtained through convenience sampling method. The researcher used convenience sampling method to collect the 143 responses from top five IT companies in greater Chennai. 
In order to justify the convenience sampling the researcher applied Cronbach Alpha criterion and found the variance above $75 \%$. Therefore the data collected through convenience sampling method are highly reliable. The collected data are subject to statistical treatments using $\mathrm{T}$ test, F-test and multiple regression analysis.

\section{ANALYSIS AND DISCUSSION}

(i)Effect Of Human resources.

In this section the researcher decided to analyse the total influence of Human resources over the employees as well as

Table -I: Coefficients(a)

\begin{tabular}{|c|c|c|c|c|c|c|}
\hline & \multirow[t]{2}{*}{ Model } & \multicolumn{2}{|c|}{ Unstandardized Coefficients } & $\begin{array}{l}\text { Standardized } \\
\text { Coefficients }\end{array}$ & \multirow[t]{2}{*}{$\mathrm{T}$} & \multirow[t]{2}{*}{ Sig. } \\
\hline & & $\mathrm{B}$ & Std. Error & Beta & & \\
\hline \multirow[t]{6}{*}{1} & (Constant) & 27.656 & 2.778 & & 9.957 & .000 \\
\hline & GS & 3.853 & 690 & .382 & 5.588 & .000 \\
\hline & RA & 1.531 & .511 & .163 & 2.998 & .003 \\
\hline & CPL & 5.071 & .956 & .392 & 5.305 & .000 \\
\hline & ED & 1.283 & .640 & .116 & 2.005 & .048 \\
\hline & $\mathrm{PA}$ & 1.215 & .557 & .105 & 2.182 & .031 \\
\hline
\end{tabular}

a Dependent Variable: IE

The regression fit is significant $(\mathrm{F}=68.698)$ and explains $77.1 \%$ variation in individual efficiency. The Human resources of different management level equally explain the individual efficiency in the organization. The practices create the organizations. The Human resources in the different management level makes the changes in the organization in the form of individual efficiency, organizational efficiency and productivity changes. The measure of impact can be determined by the statistical tool multiple regression analysis. In this context the human resource elements are considered as independent variables and effectiveness variables are considered as dependent variables. The results of regression analysis are presented below.

(ii) Effect of Human resources on organizational efficiency in IT companies :

Table -II: Coefficients (a)

\begin{tabular}{|c|c|c|c|c|c|}
\hline \multirow[t]{2}{*}{ Model } & \multicolumn{2}{|c|}{ Unstandardized Coefficients } & $\begin{array}{c}\text { Standardized } \\
\text { Coefficients }\end{array}$ & \multirow[t]{2}{*}{$\mathrm{T}$} & \multirow[t]{2}{*}{ Sig. } \\
\hline & B & Std. Error & Beta & & \\
\hline (Constant) & 24.056 & 2.656 & & 9.057 & .000 \\
\hline GS & 1.800 & .456 & .176 & 3.944 & .000 \\
\hline RA & 2.748 & .676 & .236 & 4.066 & .000 \\
\hline CPL & 3.591 & .557 & .295 & 6.449 & .000 \\
\hline ED & 4.526 & .626 & .428 & 7.233 & .000 \\
\hline PA & 1.473 & .514 & .109 & 2.866 & .005 \\
\hline
\end{tabular}

a Dependent Variable: OE (4.10)

77.1 percent variation in the individual efficiency of the employees. All the Human resources are also positively increasing the efficiency of the employees.
The regression clearly reveals that the Human resources of management explain $85.7 \%$ of variation in the organizational efficiency. The regression is significant $(F=122.501)$ and all the 5 Human resources influence the organizational efficiency of IT companies positively.

(iii) Effect of human resources on productivity in IT companies :

Table - III:Coefficients(a)

\begin{tabular}{|c|c|c|c|c|c|c|}
\hline & \multirow[t]{2}{*}{ Model } & \multicolumn{2}{|c|}{ Unstandardized Coefficients } & $\begin{array}{c}\text { Standardized } \\
\text { Coefficients }\end{array}$ & \multirow[t]{2}{*}{$\mathrm{T}$} & \multirow[t]{2}{*}{ Sig. } \\
\hline & & $\mathrm{B}$ & Std. Error & Beta & & \\
\hline 1 & (Constant) & 5.744 & 4.127 & & 1.392 & .167 \\
\hline & GS & 4.486 & .582 & .405 & 7.712 & .000 \\
\hline & RA & 2.956 & .707 & .247 & 4.179 & .000 \\
\hline & $\mathrm{CPL}$ & 4.156 & .665 & .323 & 6.248 & .000 \\
\hline
\end{tabular}




\begin{tabular}{|l|r|r|r|r|r|}
\hline ED & 3.354 & .699 & .253 & 4.797 & .000 \\
\hline PA & 7.457 & 1.102 & .420 & 6.769 & .000 \\
\hline
\end{tabular}

a Dependent Variable: PDY

From the above regression table it is found that the Human resources of different management level explain $75.5 \%$ of the productivity and Human resources in IT companies simultaneously increase the efficiency in productivity in IT companies $(F=63.027)$. The Human resources possess multiple effects over the employees of IT companies and the organization. It gives the torrent of fruitful results to increase the productivity and profitability of the organization.

\section{FINDINGS AND CONCLUSION}

The demographic variables like education, age, salary and experience for all level executives of IT companies are satisfactory and especially the experience of the employees force the executives to practice HRM to avoid unnecessary impediments to development activities. The top level executives are very much enthusiastic in implementing the Human resources, management policy in favour of organizational effectiveness, potential appraisal and organizational development for the smooth conduct of organization. The goal setting is popular in IT companies. The middle level executives consult with their superiors while they set goals for themselves. It is found that role analysis appears to be an integrated effort in all the departments. The role analysis has its maximum significance when all the departments in the two organizations are co-operative. As far as the operational level employees in IT companies are concerned they are fully satisfied about the salary and there is no significant difference among them on other demographic variables also.

\section{REFERENCES}

1. Monica Ordiz and Esteban Fernandez" Influence of the sector and the environment on human resource practices' effectiveness" International Journal. of Human Resource Management 16:8 August 2005 1349-1373 13 Routledge

2. Eric $\mathrm{Ng}$ Chee Hong, Lam Zheng Hao, Ramesh Kumar, Charles Ramendran, Vimala Kadiresan” An Effectiveness of Human Resource Management Practices on Employee Retention in Institute of Higher learning: - A Regression Analysis" International Journal of Business Research and Management (IJBRM), Volume (3) : Issue (2) : 2012 pg no-60-79

3. Darwish, Tamer K.Singh, Satwinder, Mohamed, A. Fattaah, Dec2013 "The role of strategic HR practices in organizational effectiveness: an empirical investigation in the country of Jordan".International Journal of Human Resource Management. Dec2013, Vol. 24 Issue 17, p3343-3362. 20p.

4. Maroudas, Leonidas, Kyriakidou, Olivia Vacharis, Artemis, 'Employees' motivation in the luxury hotel industry: the perceived effectiveness of human-resource practices". Managing Leisure. Jul-Oct2008, Vol. 13 Issue 3/4, p258-271. 14p

5. Stone, Dianna Stone-Romero, Eugene F ,Lukaszewski, Kimberly M. "The impact of cultural values on the acceptance and effectiveness of human resource management policies and practices." Human Resource Management Review. Jun2007, Vol. 17 Issue 2, p152-165. 14p

6. Loo-See Beha and Leap-Han Looa, "Human resource management best practices and firm performance: a universalistic perspective approach" Serbian Journal of Management 8 (2) 2013155 - 167

7. Ullah, Irfan, Yasmin, Robina, "The Influence of Human Resource Practices on Internal Customer Satisfaction and Organizational
Effectiveness." Journal of Internet Banking \& Commerce. Aug2013, Vol. 18 Issue 2, p1-28. 28p

8. Clint Chadwick "Examining non-linear relationships between human resource practices and manufacturing performance" Industrial and Labor Relations Review, Vol. 60, No. 4 (July 2007).pg 499-521

9. Heneman, Herbert G., Milanowski, Anthony T, "Assessing human resource practices alignment: A case study". Human Resource Management. Jan/Feb2011, Vol. 50 Issue 1, p45-64. 20p

10. Joaqui'n Camps and Roberto Luna-Arecas "High involvement work practices and firm performance" The International Journal of Human Resource Management, Vol. 20, No. 5, May 2009, 1056-1077 